\title{
Pengaruh Konferensi Asia Afrika (KAA) Tahun 1955 Terhadap Kemerdekaan Negara-Negara di Benua Afrika
}

\author{
Yadi Kusmayadi \\ Program Studi Pendidikan Sejarah Universitas Galuh Ciamis
}

\begin{abstract}
Abstrak
Penelitian ini bertolak dari pemikiran bahwa Konferensi Asia Afrika merupakan gagasan yang diajukan dalam Konferensi Kolombo, yang dihadiri oleh Indonesia, India, Birma, Pakistan dan Srilangka pada bulan April 1954. Selanjutnya usul tersebut di tindak lanjuti dalam Konferensi Bogor yang diadakan akhir bulan Desember 1954.Sehingga pada bulan April 1955 Konferensi Asia Afrika diselenggarakan yang dihadiri oleh 29 negara.Pengaruh Konferensi Asia Afrika terhadap negara-negara di Afrika merupakan jawaban yang positif terhadap perjuangan bangsa-bangsa terjajah terhadap kaum kolonialis yang berada di Afrika. Maka rakyat di Afrika bangkit mengadakan perlawanan terhadap penjajah bangsa Eropa Barat, menyadari akan pentingnya semangat Bandung karena mempunyai dampak yang tak ternilai terhadap gerak perjuangan dalam usaha membebaskan diri dari kaum imperialis. Konferensi Asia Afrika dapat dianggap sebagai momentum histroris yang sangat penting dalam sejarah dunia.Semangat Bandung menaikkan citra di dunia Internasional khususnya bagi bangsa Afrika.
\end{abstract}

Kata Kunci: Konferensi Asia Afrika, Kemerdekaan, Negara-Negara Afrika

\section{Pendahuluan}

Sebagai bangsa yang berbudaya wajib mempelajari dan mengetahui sejarah bangsanya, terutama sejarah yang berkaitan dengan usaha-usaha memperjuangkan kemerdekaan dari belenggu penjajahan. Dengan mempelajari sejarah akan lebih memahami makna dan arti dari perjuangan itu baik di masa lalu maupun di masa sekarang (A.H. Nasution, 1978: xx).

Dekade abad ke 20 ini dihadapkan pada corak dan arah perkembangan sejarah manusia yang berbeda dengan corak sejarah manusia sebelumnya. Corak dan arah yang ditandai oleh bangkitnya golongan bangsabangsa yang dijajah oleh kaum kapitalis, menurut persamaan hak, harga diri dan kedaulatan atau lebih tegas mereka menuntut kemerdekaan abadi lepas dari pengaruh-pengaruh asing bersatu berkumpul untuk menyatakan cita-cita, membantu kawan, tetangga ikut berjuang merebut kemerdekaan. Indonesia pernah membuktikan sikap solidaritas itu, yaitu terciptanya solidaritas bangsa-bangsa Asia Afrika yang terkenal dengan sebutan "Semangat Bandung" pada tahun 1955.(Said Hamid Hasan, 1994: 747).

Tentu saja Semangat Bandung masih relevan untuk politik luar negeri kita yang bebas aktif. Konferensi Asia Afrika masih mempunyai arti penting dan besar pengaruhnya hingga sekarang, terutama bagi negara yang cinta damai. Konferensi Asia Afrika menaikan citra Indonesia merupakan bukti untuk membentuk opini publik di mata dunia internasional, khususnya bagi bangsa Asia Afrika yang 
mendambakan kemerdekaan dan perdamaian (Sartono Kartodirdjo, 1977: 378).

Selama Indonesia memegang teguh Pancasila dan berdasarkan negara kesatuan Republik Indonesia yang diproklamasikan pada tanggal 17 Agustus 1945 sebagai Landasan berbangsa dan bernegara, maka Semangat Bandung tetap menjadi "Way of Prinsiple" politik luar negeri Indonesia yang bebas aktif. Semangat Bandung tercantum secara utuh didalam pembukaan Undangundang Dasar 1945 yaitu "perdamaian abadi berdasarkan kemerdekaan dan keadilan sosial" (Ketetapan MPR, Nomor II/MPR/1978, 1).

Indonesia merdeka tahun 1945, maka bangsa-bangsa yang terjajah mulai melepaskan diri dari belenggu penjajahan untuk mewujudkan cita-cita proklamasinya. Sementara bangsa penjajah mulai goyah kedudukannya, karena satu persatu negara jajahan mulai memproklamasikan kemerdekaannya. Diantaranya Indonesia (17 Agustus 1945), Republik Vietnam (1945), dan negara-negara di Afrika seperti, Libia (1951) dan negara-negara lainnya. (Kosoh Sastradinata, dan Rusyai Padmawijaja, 1977: 63).

Untuk lebih mengeratkan rasa persatuan serta menjaga kestabilan di kawasan Asia Afrika, Indonesia memprakarsai pertemuan dalam pencaturan politik dunia dengan cara menyelenggarakan Konferensi Asia Afrika pada tanggal 18-24 April 1955 di Bandung (Soebantardjo, 1956:252).

\section{Tinjauan Pustaka}

\section{A. Konstelasi Politik Dunia menjelang} pelaksanaan Konferensi Asia Afrika

Berakhirnya Perang Dunia kedua pada bulan Agustus 1945, tidak identik dengan berakhirnya situasi permusuhan di antara bangsa-bangsa di dunia sehingga kemudian tercipta perdamaian dan keamanan. Di beberapa belahan dunia, terutama di benua Asia Afrika. masih banyak masalah yang mengakibatkan permusuhan terus berlangsung. Bahkan pada tingkat perang terbuka seperti di wilayah Korea, Indo-Cina. Palestina. Afrika Selatan, dan Afrika Utara (Dodi R. Iskandar, 1994: 17).

Masalah-masalah tersebut di atas. sebagian disebabkan oleh lahirnya dua blok kekuatan raksasa yang bertentangan, baik secara ideologis maupun secara kepentingan, yaitu blok Barat dan blok Timur. Saat itu blok Barat dipimpin oleh Amerika Serikat dan blok Timur dipimpin oleh Uni Soviet, setiap blok berusaha untuk menarik negara-negara d Asia dan Afrika agar menjadi pendukung mereka masingmasing.

Hal ini mengakibatkan tetap hidupnya dan bahkan tumbuhnya suasana permusuhan yang terselubung di antara kedua blok beserta para pendukungnya. Suasana permusuhan demikian terkenal 
dengan sebutan perang dingin (Departemen Luar Negeri RI. 1992: 10). Timbulnya pergolakan dunia disebabkan pula oleh masih adanya penjajahan di bumi mi. terutama di belahan Asia dan Afrika.

$$
\text { Sebelum Tahun } 1945 \text { pada }
$$

umumnya benua Asia dan Afrika merupakan wilayah jajahan bangsa Barat dalam berbagai bentuk. Tetapi sejak tahun 1945 banyak daerah di Asia Afrika menjadi negara merdeka dan banyak pula yang masih atau sedang berjuang mewujudkan kemerdekaan negara dan bangsa mereka, seperti Aljazair, Tunisia, dan Maroko di wilayah Afrika Utara, Vietnam di Indo-Cina, dan wilayah-wilayah di ujung selatan Afrika.

Perlu dicatat pula bahwa beberapa negara Asia Afrika yang telah merdeka pun masih hanyak yang menghadapi masalah sisa-sisa penjajahan, seperti Indonesia tentang Irian Barat. India dan Pakistan tentang Kashmir. negara-negara Arab tentan Palestina sebagian bangsa Arab-Palestina terpaksa mengungsi, karena tanah air mereka diduduki secara paksa oleh pasukan Israel yang dibantu oleh kekuatan pemimpin raksasa blok Barat (Bakran Asmawi, 1985 57).

Sementara itu bangsa-bangsa di dunia, terutama bangsa-bangsa Asia Afrika, sedang dilanda kekhawatiran akibat makin dikembangkannya pembuatan senjata nuklir yang bisa memusnahkan umat manusia secara dahsyat, sejumlah negara Asia Afrika yang telah merdeka pun muncul konflik antar kelompok masyarakat sebagai akibat masa penjajahan politik adu domba dan perang dingin antar blok dunia tersebut di atas (Nana Supriatna, 2002 66). Walaupun pada masa itu telah ada badan internasional yaitu Persatuan Bangsabangsa (PBB), yang berfungsi menangani masalah-masalah dunia, namun kenyataannya badan ini belum berhasil menyelesaikan semua persoalan yang timbul. Sedangkan kenyataan pula bahwa akibat-akibat yang ditimbulkan oleh masalah-masalah tersebut di atas. sebagian besar diderita oleh bangsa-bangsa di Asia Afrika. Keadaan itulah yang melatarbelakangi lahirnya gagasan untuk mengadakan Konferensi Asia Afrika(Nana Supriatna, 2002: 13).

\section{B. Pelaksanaan Konferensi Asia Afrika}

Kerjasama antar negara-negara di Asia Afrika yang merupakan wilayah penjajahan oleh bangsa-bangsa Barat telah menjadi bahan pemikiran menteri luar negeri di Era tahun 1950-an. Keterangan pemerintah Indonesia tentang politik luar negeri di depan parlemen yang disampaikan oleh Perdana Menteri Mr. Ali Sastroamidjojo pada tanggal 25 Agustus 1953 menyatakan:

Kerjasama dalam golongan negaranegara Asia-Arab (Afrika) kami pandang penting benar karena kami yakin, bahwa kerja sama erat antara negara-negara tersebut tentulah akan memperkuat usaha ke arah tercapainya perdamaian dunia yang kekal. Kerjasama antara negara-negara Asia Afrika tersebut adalah sesuai benar dengan aturan-aturan dalam PBB 
(Persatuan Bangsa-bangsa) yang menyenangi kerja sama kedaerahan (regional arrangement). Lain dan itu negara-negara itu pada umumnya memang mempunyai pendirianpendirian yang sama dalam beberapa soal di lapangan internasional. jadi mempunyai dasar sama (common ground) untuk mengadakan golongan yang khusus. Dan sebab itu kerja sama tersebut akan kami lanjutkan dan pererat" (Departemen Luar Negeri RI. 1992:11).

Keterangan tersebut mencerminkan ide dan kehendak pemerintah Indonesia untuk mempererat kerjasama di antara negara-negara Asia-Afrika, senantiasa mendambakan perdamaian dan sesuai dengan aturan-aturan dalam PBB. Gagasan untuk mengadakan suatu konferensi bangsa-bangsa Asia dan Afrika, diabadikan pada perjuangan kemerdekaan bangsabangsa yang terjajah.

Usaha untuk mencapai perdamaian, telah lahir di Colombo pada tahun 1954 ketika para Perdana Menteri dan Burma (U $\mathrm{Nu}$ ), Sri Langka (Sir John Kotelawala), India (Jawaharlal Nehru), Indonesia (Ali Sastroamidjojo) dan Pakistan (Muhammad Ali Jinnah), mengadakan pertemuan untuk bertukar pikiran dan membicarakan masalah-masalah yang menyangkut kepentingan serta keprihatinan bersama (Bakran Asmawi, 1985: 12).

Dalam pertemuan tersebut, Perdana

Menteri Indonesia mengusulkan agar diadakan suatu pertemuan bangsa-bangsa Asia dan Afrika dengan tujuan mempererat kerjasama antara mereka guna meningkatkan usaha-usaha ke arah perdamaian dunia (Bakran Asmawi, 1985: 13).

Dalam mengusulkan konferensi tersebut, Perdana Menteri Ali Sastroamidjojo mengulangi kembali tujuan penting dan politik luar negeri Indonesia untuk pertama kali diucapkan di muka umum bulan Agustus 1953 saat menyampaikan program kabinet kepada Dewan Perwakilan Rakyat, yaitu:

Karena kita yakin bahwa kerjasama yang erat antara negara-negara Asia Afrika akan memperkuat usaha-usaha ke arah mencapai perdamaian dunia yang abadi. maka kita menganggap kerjasama antara negara-negara itu sangat penting. Kerjasama antara negara Asia dan Afrika adalah sesuai dengan Piagam Perserikatan BangsaBangsa mengenai pengaturanpengaturan regional. Lagi pula negaranegara ini, umumnya mempunyai pandangan-pandangan yang sama terhadap beberapa aspek di bidang hubungan internasional. Dengan demikian, terdapatlah kesamaan dasar untuk pembentukan suatu kelompok yang khusus. Mulai dan sekarang kita akan meneruskan dan memperkuat kerjasama antara negara-negara ini (Mochtar Kusumaatmadja, 1983: 88).

Pernyataan tersebut bahwa melalui kerja sama dengan bangsa-bangsa Asia dan Afrika lain, Indonesia menegaskan posisi dan memperdengarkan suaranya terhadap persoalan dunia, khususnnyamengenai Asia dan Afrika. Hal ini menandai maksud Indonesia di bawah pimpinan Perdana Menteri Ali Sastroamidjojo untuk 
memainkan peranan dalam percaturan dunia melalui bekerjasama dengan negaranegara Asia dan Afrika lainnya (Mochtar Kusumaatmadja. 1983: 89).

Disamping itu, pertemuan Colombo telah memberikan kesempatan pertama untuk melancarkan gagasan ini dan untuk mendapatkan penerimaan lebih luas. Walaupun penerimaannya tidak terlalu hangat, pertemuan Colombo sebenarnya tidak menentang gagasan tersebut, dan akhirnya dimasukkan dalam akhir Komunike Bersama Colombo.

Di dalam komunike tersebut ada suatu ayat yang menyatakan bahwa: ... para Perdana Menteri membicarakan baik tidaknya untuk mengadakan suatu Konferensi Bangsa-Bangsa Asia Afrika dan mendukung agar Perdana Menteri Indonesia menjajaki kemungkinan diadakannya Konferensi yang demikian (Panitia Penulisan Sejarah Deplu. 1983: 209). Dengan demikian, lahirlah gagasan untuk mengadakan Konferensi BangsaBangsa Asia Afrika (Bakran Asmawi, 1985: 15).

Langkah pertama untuk membawa gagasan ini adalah Pertemuan Bogor pada bulan Desember 1954, para Perdana Menteri Burma, India, Indonesia, Pakistan dan Sri Langka bertemu di Bogor, Indonesia atas undangan Perdana Menteri Indonesia. Jika di Colombo belum terdapat kesatuan pendapat mengenai baik tidaknya diadakan konferensi bangsa-bangsa Asia dan Afrika, maka ketika Perdana Menteri bertemu di Bogor tercapai kesatuan pandangan untuk mengadakan konferensi demikian. Di samping menyetujui, bahwa konferensi itu harus mendapatkan dukungan bersama dalam pelaksanaannya.Para Perdana Menteri memutuskan bahwa pertemuan ini diadakan di Indonesia bulan April 1955 (Roeslan Abdulgani, T.T.: 321).

Para Pemimpin Burma, India, Indonesia, Pakistan, dan Sri Langka sadar akan nasib bangsa-bangsa yang waktu itu belum merdeka di Asia dan Afrika serta gangguan terhadap perdamaian dan stabilitas politik dunia, dengan demikian sepakat, bahwa bangsa-bangsa di dunia yang baru merdeka itu, perlu bekerja sama dan memainkan peranannya dalam usaha bersama. Tujuannya untuk membangun dunia yang lebih baik, di mana semua bangsa dapat bekerja sama untuk kesejahteraan rakyatnya dan untuk perbaikan dunia serta umat manusia seluruhnya.

Di dalam suatu dunia yang dibebani dengan sisa kolonialisme dan imperialisme dimana perbedaan berdasarkan suku bangsa, agama, dan asal-usul sosial tersebar luas dan perjuangan rakyat meningkat untuk menumbangkan penjajahan kolonial, maka tepat kemerdekaan dan kebebasan bangsa yang terjajah dianggap sebagai prasyarat yang harus dipenuhi bagi usaha untuk membangun dunia yang baru dan lebih baik (Roeslan Abdulgani, T.T.: 322). 
Kejadian di Korea awal tahun 1950an merupakan gejala keadaan dunia yang tercekam dalam Perang Dingin. Perang kemerdekaan di Indo-cina melawan Perancis menyebabkan diadakannya konferensi di Genewa untuk menyelesaikan konflik tersebut. Keadaan di dunia nampak jauh dan pada memberi harapan, baik untuk melakukan usaha seperti yang telah diputuskan kelima negara ini (Bakran Asmawi, 1985: 129).

Sesuai dengan garis haluan politik luar negeri, Indonesia menerima petunjuk sebagai penyelenggara Konferensi Asia Afrika. Gagasan KAA atas putusan Konferensi Colombo, atas usul Ali Sastroamidjojo sebagai utusan pemerintah Republik Indonesia (Bakran Asmawi, 1985:

11). Pertemuan Bogor dikenal sebagai Konferensi Panca Negara, karena pertemuan ini dihadiri perdana menteri kelima negara sponsor, yaitu:

1. Indonesia, diwakili oleh perdana menteri Ali Sastroamidjojo,

2. India, diwakili oleh perdana menteri Jawaharlal Nehru,

3. Pakistan, diwakili oleh perdana menteri Mohammad Ali,

4. Burma, diwakili oleh perdana menteri $U$ $\mathrm{Nu}$,

5. Srilangka, diwakili oleh perdana menteri Sir John Kotelawala (Bakran Asmawi, 1985: 12)

Konferensi Pancanegara di Bogor berhasil menyusun keputusan, seperti tanggal, bulan atau lamanya pelaksanaan konferensi, negara yang akan diundang, serta menetapkan rancangan agenda konferensi, dan merumuskan pokok tujuan KAA. Konferensi Colombo dan Pancanegara di Bogor merupakan pelopor KAA di Bandung tahun 1955.

KAA dibuka 18 April 1955 di Gedung Merdeka Bandung. Konferensi tersebut dihadiri 29-30 negara undangan. Satu negara tidak dapat hadir yaitu Federasi Afrika Tengah (Rhodesia dan Nyasa).Hal ini karena sedang mengalami pergolakan politik, yaitu penduduk asli yang berkulit hitam sedang menentang diskriminasi ras,perlakuan dan hak karena perbedaan warna kulit oleh penguasa kulit putih (Bangsa Eropa)(Nana Supriatna, 2002: 15).

Adapun dua puluh sembilan negara AsiaAfrika yang hadir dalam KAA, ialah: Indonesia, India, Burma, Pakistan, Srilangka, Afghanistan, Kambodja, Republik Rakyat Cina, Mesir, Ethiopia, Ghana, Iran, Irak, Jepang, Yordania, Laos, Libanon, Liberia, Libya, Nepal, Philipina, Saudi Arabia, Sudan, Syria, Muang Thai, Turki, Vietnam Utara, Vietnam Selatan (Departemen Luar Negeri RI, 1992: 24).

Selain itu, tujuan Konferensi Asia Afrika adalah:

1. Memajukan kerjasama, persahabatan, perhubungan antara bangsa-bangsa Asia dan Afrika untuk menyelenggarakan kepentingan bersama. 
2. Kerjasama dalam lapangan sosial, ekonomi, kebudayaan di antara bangsabangsa Asia Afrika.

3. Memecahkan bersama soal-soal khusus dan penting bagi bangsa-bangsa Asia Afrika, seperti: menjamin kedaulatan, melenyapkan diskriminasi ras dan penjajahan.

4. Memperbesar peranan Asia Afrika dalam dunia sekarang dan ikut serta mengusahakan perdamaian dunia (Nana Supriatna, 2002: 13)

Konferensi Asia Afrika ini dihadiri oleh 23 negara Asia dan 6 negara Afrika. Dalam konferensi ini ada tiga golongan yang berlainan pendirian politik negaranya, yaitu:

1. Golongan Barat, seperti Philipina, Muang Thai, Pakistan, Iran, Turki,

2. Golongan yang beraliran Komunis, seperti RRC, Vietnam Utara,

3. Golongan Netral seperti India, Burma, Srilangka dan Indonesia (Panitia Penulisan Sejarah Deplu, 1983: 209).

Sedangkan negara peserta yang lain tidak menampakkan pendiriannya. Berkat kesadaran negara peserta yang lebih mengutamakan persamaan dan pada perbedaan, maka konferensi dapat berjalan lancar (Dodi R, Iskandar, 1987: 51).

Dalam Konferensi Asia Afrika di Bandung tokoh bangsa Indonesia yang memegang peranan penting, ialah: Ali Sastroamidjojo sebagai Ketua Konferensi; Ruslan Abdulgani sebagai Sekretaris
Jenderal, Muhammad Yamin menjadi Ketua Komite Kebudayaan, Prof. Jr. Rooseno sebagai Ketua Komite Ekonomi (Departemen Luar Negeri, 1992: 17).

Negara-negara lain nampak pula para diplomat terkenal seperti Cou En-Lai (RRC), Jawaharlal Nehru dan Khnisna Menon (India), U Nu (Burma), Carlos Romulo (Philipina), Van Vaithayakon (Muang Thai), Sir John Kotelawala (Srilangka), Norodom Sihanouk (Kamboja), Muhammad Ali (Pakistan) dan Gamal Abdul Naser (Mesir).

Komposisi delegasi dan 29 Negara yang menghadiri Konferensi Asia Afrika di Bandung pada tanggal 18 sampai 24 April 1955, termasuk tamu, pegawai sekretariat, atau staf yang menyertai delegasi-delegasi ke Bandung melebihi 400 orang (Panitia Penulisan Sejarah Deplu, 1983: 210). Konferensi Asia Afrika yang diselenggarakan 18-24 April 1955 di Bandung telah berhasil meninjau masalah yang menyangkut kepentingan bersama negara-negara Asia dan Afrika.

\section{Hasil-hasil Konferensi Asia Afrika}

Beberapa keputusan yang berhasil disepakati bersama oleh segenap peserta adalah sebagai berikut:

1. Kerjasama Ekonomi:
a) mengusahakan kemajuan ekonomi.
b) saling memberikan bantuan teknik.
c) memajukan perdagangan.
d) mendirikan bank-bank. 
2. Kerjasama Kebudayaan:

a. memajukan kerjasama kebudayaan sebagai jalan terpenting untuk mendapatkan pengertian antara bangsa-bangsa Asia Afrika.

b. memajukan pendidikan dan pengajaran dengan pertukaran pelatih, guru, pelajar.

3. Hak-hak Asasi Manusia:

a. menjunjung tinggi hak-hak asasi manusia seperti yang tercantum dalam "Universal Declaration of Human Right" dan Perserikatan Bangsa-Bangsa (PBB).

b. menentang adanya diskriminasi ras

4. Soal Bangsa-bangsa yang Belum Merdeka:

a. menentang adanya penjajahan dalam segala bentuk apapun juga

b. menuntut kemerdekaan bagi Aljazair, dan Maroko.

5. Soal-soal Lain:

a. mengakui hak-hak Arab di Palestina dan menuntut soal Palestina diselesaikan secara damai.

b. menuntut kembalinya wilayah Irian Jaya kepada Indonesia

c. menuntut hak wilayah Aden bagi Yaman.

6. Mengusahakan Perdamaian Dunia dan Kerjasama Dunia:

a. mengusulkan supaya negara-negara yang telah memenuhi syarat-syarat Piagam PBB diterima menjadi anggotanya seperti : Jepang, Srilangka,
Kambodja, Laos, Vietnam, Yordania, Libia, dan Nepal.

b. mengusulkan supaya diadakan larangan atas pembuatan, percobaan, dan penggunaan senjata atom.

c. mengusulkan diadakan pengurangan persenjataan.

d. mengusulkan diadakan kerjasama semu negara-negara di seluruh dunia atas dasar menghormati hak-hak manusia, dan seterusnya (Nana Supriatna, 2002: 13-14)

Setelah melalui sidang-sidang yang menegangkan dan melelahkan selama satu minggu, maka pada jam 19.00 malam (terlambat dua jam dan yang direncanakan semula) tanggal 24 April 1955 sidang umum terakhir Konferensi Asia Afrika dibuka. Dalam sidang umum itu dibacakan oleh Sekretaris Jenderal Konferensi rumusan pernyataan dan tiap-tiap panitia sebagai hasil konferensi. Sidang umum menyetujui seluruh pernyataan tersebut. Selanjutnya, sidang umum ditem51 dengan sambutan para ketua delegasi. Dan setelah itu. Ketua Konferensi menyampaikan pidato penutupan dan menyatakan bahwa Konferensi Asia Afrika ditutup. (Bakran Asmawi, 1985: 45)

Dalam komunike terakhir diantaranya dinyatakan bahwa Konferensi Asia Afrika telah meninjau soal-soal yang mengenai kepentingan bersama negaranegara Asia dan Afrika dan telah merundingkan cara-cara bagaimana rakyat 
negara-negara mi dapat bekerjasama dengan lebih erat di lapangan ekonomi, kebudayaan, dan politik. Yang paling mashur dan hasil konferensi mi ialah apa yang kemudian dinamakan Dasa Sila Bandung. Yaitu suatu pernyataan politik Yang berisi prinsip-prinsip dasar dalam usaha memajukan perdamaian dan kerja sama dunia (Departemen Luar Negeri RI, 1992: 320)

Adapun kesepuluh prinsip tersebut, ialah:

1. Menghormati hak-hak dasar manusia dan tujuan-tujuan serta azas-azas yang terdapat dalam piagam PBB.

2. Menghormati kedaulatan dan integritas teritorial semua bangsa-bangsa.

3. Mengakui persamaan semua suku-suku bangsa dan persamaan semua bangsabangsa besar maupun kecil.

4. Tidak melakukan intervensi atau campur-tangan dalam soal-soal dalam negeri negara lain.

5. Menghormati hak tiap-tiap bangsa untuk mempertahankan diri sendiri secara sendirian atau secara kolektif, yang sesuai dengan piagam PBB.

6. a. Tidak mempergunakan peraturan dan pertahanan kolektif untuk bertindak bagi kepentingan khusus dan salah satu dan negara-negara besar.

b. Tidak melakukan tekanan terhadap negara lain.

7. Tidak melakukan tindakan-tindakan atau ancaman agresi ataupun penggunaan kekerasan terhadap integritas teritorial atau kemerdekaan politik semua negara.

8. Menyelesaikan segala perselisihanperselisihan internasional dengan jalan damai, seperti perundingan, persetujuan, arbitrase atau penyelesaian hakim ataupun lain-lain cara damai lagi menurut pilihan pihak-pihak yang bersangkutan, yang sesuai dengan piagam PBB.

9. Memajukan kepentingan bersama dan kerja sama.

10. Menghormati hukum dan kewajibankewajiban internasional (Sekretariat Negara Rl, 1986: 80)

Dalam penutup komunike terakhir dinyatakan bahwa Konferensi Asia Afrika menganjurkan supaya kelima negara penyelenggara mempertimbangkan diadakannya pertemuan berikutnya dan konferensi ini, dengan meminta pendapat negara-negara peserta lainnya. Tetapi usaha untuk mengadakan Konferensi Asia Afrika kedua selalu mengalami hambatan yang sulit diatasi. Tatkala usaha itu hampir terwujud (1964), tiba-tiba di negara tuan rumahnya (Aljazair) terjadi pergantian pemerintahan, sehingga konferensi itu tidak jadi (Departemen Luar Negeri RI, 1992 : 382).

Konferensi Asia Afrika di Bandung bagaimanapun juga telah berhasil menggalang persatuan dan kerja sama di antara negara-negara Asia dan Afrika, baik 
dalam menghadapi masalah internasional, maupun masalah regional. Konferensi serupa bagi kalangan tertentu di Asia Afrika beberapa kali diadakan pula, seperti Konferensi Wartawan Asia Afrika. Konferensi Islam Asia Afrika. Konferensi Pengarang Asia Afrika. Konferensi Mahasiswa Asia Afrika. Konferensi Asia Afrika telah membakar semangat dan menambah kekuatan moral para pejuang bangsa-bangsa Asia Afrika yang masa itu tengah memperjuangkan kemerdekaan tanah air mereka, sehingga kemudian bermunculanlah sejumlah negara merdeka di benua Asia dan Afrika.

Semua itu menandakan bahwa citacita dan semangat Dasasila Bandung semakin merasuk ke dalam tubuh bangsabangsa Asia dan Afrika. Konferensi ini menghasilkan berbagai keputusan penting yang dituangkan di dalam suatu komunike bersama. Di samping itu pula disetujui prinsip-prinsip hubungan internasional dalam rangka memelihara dan memajukan perdamaian dunia. Prinsip-prinsip tersebut dikenal dengan "Dasasila Bandung”.

\section{Metode Penelitian}

Sesuai dengan masalah yang diteliti dan dikaji yaitu peristiwa di masa lampau, maka metode yang digunakan dalam penelitian ini adalah metode sejarah (Historis). Metode sejarah adalah instrumen untuk merekonstruksi peristiwa sejarah (history as past actuality) menjadi sejarah sebagai kisah (history as written). Metode sejarah mencakup empat tahap Tahapan. (1), heuristik (mencari sumber-sumber), (2) kritik atau analisis (menilai sumbersumber), (3) interpretasi atau sintesis (menafsirkan keterangan sumber-sumber), dan (4) historiografi (penulisan sejarah) (Notosusanto dalam Priyadi, 2012: 3).

\section{Hasil Dan Pembahasan}

A. Kebangkitan Negara di Afrika untuk Menuju Kemerdekaan

\section{Negara Afrika Yang Merdeka Sebelum} Konferensi Asia Afrika Tahun 1955

Kebangkitan nasional bangsa-bangsa Asia dan Afrika merupakan keinginan dan cita-cita kebangsaan yang mengandung aspek politik, ekonomi dan sosial budaya. Secara politik, kebangkitan Asia Afrika merupakan suatu gerakan untuk menyumbangkan Dominasi politik kaum imperialis.

Di samping itu secara ekonomis pergerakan nasional Asia Afrika juga bermaksud menghentikan eksplorasi ekonomi, dan bertujuan membangun tata masyarakat baru yang bebas dari kesengsaraan dan kemiskinan sesuai dengan cita-cita keadilan sosial, dan kebudayaan asing yang tidak sesuai dengan kepribadian bangsa sendiri berusaha untuk disingkirkan karena kebudayaan asing itu lebih banyak merugikannya dari pada menguntungkannya (Kosoh Sastradinata, 1985: 2). Pergerakan nasional sebagai salah satu bentuk kebangkitan negara-negara dan 
bangsa Asia Afrika membuahkan hasil berupa kemerdekaan bagi bangsa-bangsa terjajah pada pertengahan abad ke 20 .

Dengan kemerdekaan yang diperoleh itu bangsa-bangsa Asia Afrika membangun negaranya secara bebas sesuai dengan kepribadiannya masing-masing. Setelah mengalami beberapa kali proses pembangunan, negara-negara Asia Afrika pada akhir abad ke 20 mulai muncul sebagai negara yang ekonominya kuat, sedangkan dalam bidang kebudayaan mereka sudah mulai dapat menemukan kepribadiannya.

Dengan demikian perlu kiranya penulis menggambarkan beberapa negara yang sudah merdeka sebelum pelaksanaan Konferensi Asia Afrika tahun 1955 di Bandung. Adapun negara-negara Afrika yang memperoleh kemerdekaan sebelum pelaksanaan Konferensi Asia Afrika tahun 1955 di Bandung adalah sebagai berikut:

Tabel 1. Negara Afrika Yang Merdeka Sebelum Konferensi Asia Afrika Tahun 1955 Bandung

\begin{tabular}{|l|l|l|l|}
\hline No & Nama Negara & Merdeka & $\begin{array}{l}\text { Bekas } \\
\text { Jajahan }\end{array}$ \\
\hline 1 & Afrika Selatan & 1910 & Inggris \\
2 & Liberia & 1947 & Inggris \\
3 & Ethiophia & 1941 & Italia \\
4 & Mesir & 1953 & Inggris \\
5 & Libya & 1951 & Turiki, Italia \\
\hline
\end{tabular}

Sumber : Kosoh Sastradinata, 1977

Berdasarkan daftar tabel diatas, pada umumnya negara-negara dikawasan Afrika mempunyai persamaan sejarah satu sama lain yaitu pernah dijajah oleh bangsabangsa Eropa.

\section{Negara-negara Afrika Yang Merdeka} Sesudah Konferensi Asia Afrika

\section{Tahun 1955 Bandung.}

Sebelum Perang Dunia II, sebagian besar negara-negara di Benua Afrika merupakan daerah jajahan kaum Imperialis Barat. Pada akhir Perang Dunia II, kaum kolonis menginjakan kakinya di bumi Afrika. Maka rakyat di negara-negara Afrika serentak melakukan perjuangan yang gigih untuk mengusir kaum kolonialis dan imperialis Barat.

Afrika bukan lagi negara gelap, kini banyak rakyat Afrika meninggalkan kehidupan primitifnya menuju masyarakat yang agresif dan modern seperti orangorang Barat perkembangannya sangat cepat sekali terutama dalam bidang politik dan ekonomi, tetapi bidang sosial, kebudayaan dan kepercayaan pun dapat berkembang (Widjaja, 1986:30).

Banyak pemuda-pemuda Afrika yang belajar di Perguruan Tinggi dan berhasil memperoleh gelar sarjana.Khusus bidang keagamaan, banyak sekali yang sudah menganut kepercayaan Nasrani dan Islam setelah meninggalkan kepercayaan primitifnya (Kosoh, 1977: 4). Selanjutnya penulis sajikan dalam tabel dibawah ini negara-negara Afrika yang merdeka Pasca Konferensi Asia Afrika. 
Tabel 2. Daftar Negara Afrika Yang Merdeka Sesudah Konferensi Asia Afrika Tahun 1955 Bandung

\begin{tabular}{|l|l|l|l|}
\hline No & Nama & Merdeka & Bekas Jajahan \\
\hline 1 & Sudan & 1956 & Prancis \\
2 & Tunisia & 1957 & Prancis \\
3 & Maroko & 1957 & Prancis \\
4 & Aljazair & 1962 & Prancis \\
5 & Kenya & 1964 & Inggris \\
\hline
\end{tabular}

Sumber : Kosoh Sastradinata, 1977

Berdasarkan pernyataan di atas, pergerakan nasionalis di Afrika Utara yang dipelopori oleh Libya, Mesir, Aljazair, Tunisia, dan Maroko, akhirnya bergema juga pengaruhnya ke negara jajahan Barat lain. Pasca Perang Dunia II, di Afrika Utara terdapat negara baru, seperti; Senegal (1960), Mali (1960), Pantai Gading (1960), Ghana (1957) dan Siera Leone (1961). Kemerdekaan sebagian besar negara Afrika Utara, selain dipengaruhi oleh hal-hal yang dikemukakan di atas, juga merupakan pengaruh langsung diselenggarakannya Konferensi Asia Afrika Bandung ke 1 tahun 1955 (Kosoh, 1977: 97-102\&103).

\section{B. Kebangkitan Negara-negara di Afrika 1. Kebangkitan Sudan}

Ketika terdengar suatu cerita tentang adanya tambang emas di Sudan, Muhamad Ali tokoh pembaharu Mesir memerintahkan tentaranya di bawah pimpinan Defterday Bey untuk menyerbu Sudan. Akhirnya Sudan berhasil di duduki, maka kota Sudan menjadi milik Mesir dan Defterday Bey dianggap sebagai pembangun kota Khartoum (Soebantardjo, 1956: 190). Sudan merupakan daerah penting bagi
Imperialisme Mesir dan Barat. Imperialisme Barat yang datang ke Mesir adalah Inggris. Sehingga Inggris menguasai Mesir, dengan sendirinya Inggris mulai mengalihkan perhatian ke Sudan dengan cara memperalat Mesir. Dalam tahun 1899 secara formil Sudan menjadi negara "AngloEgyption Sudan" (Kosoh, 1977: 60).

Sebelum Jenderal Gordon, telah banyak opsir-opsir Inggris ditempatkan di Mesir dan Sudan. Tetapi sebelum maksud Inggris menguasai Sudan terlaksana, timbul pemberontakan yang dipimpin oleh Imam Mahdi.Muhammad Ahmad yang menamakan dirinya Al-Mahdi mengadakan pemberontakan terhadap Inggris untuk memerdekakan Sudan dari Mesir dan membentuk kerajaan Mahdi di Sudan (Soebantardjo, 1956: 198).

Sementara itu di Sudan terjadi perpecahan alam kongres, partai-partai politik terbesar yang muncul sesudah pecah partai yaitu partai Ashingga dan Umma. Partai yang pertama mewakili kepentingan golongan berjuis nasional anggotanya terdiri dari kaum pedagang, pegawai negeri dan sebagainya. Tuntutannya ialah Pembebasan dari penjajahan Inggris dan penggabungan kepada Mesir. Partai Umma mewakili kepentingan kaum feodal dan kaum berjuis yang mempunyai hubungan dengan modal Inggris. Partai ini juga menuntut kemerdekaan, tetapi menyukai ikatan erat dengan Inggris. Sebagian besar dari anggota-anggotanya terdiri dari kaum 
tuan tanah, ulama, dan pegawai tinggi pribumi dalam pemerintahan kolonial.

Pada akhir tahun 1948 terbentuk organisasi progresif baru. Gerakan rakyat Sudan untuk Pembebasan nasional yang didalamnya turut aktif kaum pekerja dan golongan terpelajar. Tuntutan kemerdekaan dari rakyat Sudan semakin santer. Keputusan dari parlemen Mesir pada 15 Oktober 1951, yaitu pembatalan persetujuan Inggris-Mesir tahun 1936 dan mengenai "Kondominion Sudan" tahun 1899 mendorong rakyat Sudan untuk mengadakan aksi lebih tegas lagi. Dengan inisiatif dari gerakan Sudan untuk Pembebasan nasional oleh semua partai dan golongan organisasi, kecuali partai Umma yang reaksioner diadakan front Persatuan Nasional.

Revolusi nasional tahun 1952 di Mesir mengakhiri pemerintah Kondominion di Sudan dengan Inggris harus mendatangani persetujuan dengan Mesir untuk memberikan hak pemerintahan sendiri kepada Sudan. Dalam bulan November 1953 rakyat Sudan memilih parlemennya yang pertama yang diakui dengan penyusunan pemerintahan nasional untuk membangun negara baru. (Soebantardjo, 1956 : 203).

Dalam bulan Agustus 1955 Parlemen Sudan dengan pendapat bulat, memutuskan untuk menghapuskan pemerintahan Inggris dan menuntut penarikan semua pasukan asing. Kemudian bulan Desember tahun itu juga di putuskan untuk memproklamasikan Sudan sebagai Republik yang merdeka pada 1 Januari 1956, maka berdiri Sudan merdeka.

\section{Kebangkitan Tunisia}

Pergerakan terjadi juga dinegara jajahan Perancis yaitu Tunisia. Sebelum menjadi negara merdeka Tunisia mengadakan pergerakan untuk memperoleh kemerdekaannya. Ketika Perang Dunia I, Tunisia memihak Perancis dan berada dipihak yang menang. Setelah perang selesai, suatu Delegasi Tunisia di bawah pimpinan Abdul Aziz Taalbi mendatangi Paris untuk meminta agar Tunisia memperoleh hak untuk menentukan nasibnya sendiri.

Perancis menolak tuntutan Abdul Aziz dan atas penolakan tersebut Abdul Aziz mendirikan partai Destour yang bertujuan untuk mengadakan gerakan merebut kemerdekaan dari tangan Prancis. Karena banyak yang tidak setuju dengan cara kooperatif yang dijalankan partai Destour maka timbulah kelompok baru yang menanamkan dirinya kelompok NeoDestour yang kemudian menjadi Partai Nasional Tunisia (Kosoh, 1977).Setelah berjuang beberapa waktu lamanya akhirnya Tunisia memperoleh kemerdekaan pada tahun 1957 dengan Presiden yang pertama Habib Bourgiba (Kosoh, 1977: 68).

\section{Kebangkitan Maroko}

Sementara itu kebangkitan nasional Maroko dilakukan terhadap kaum penjajah 
Spanyol-Prancis yang bercokol di Maroko sejak tahun 1981. Kaum nasional di bawah pimpinan Abdul Karim mengadakan perlawanan terhadap penjajahan, namun tindakan Abdul Karim itu dapat dipadamkan oleh Jenderal Petain (Kosoh, 1977: 70).

Ketika Perang Dunia II di Maroko berdiri Partai Istiglal yang menuntut kemerdekaan penuh atas Maroko. Partai itu mendapat perlindungan dari Sultan Muhammad bin Yusuf yang berkuasa di Maroko setelah Sultan diturunkan dari tahta, ia dibuang dan tahta kerajaan diduduki oleh Maoley Muhammad Aarafa yang pro Prancis. Kaum nasionalis tetap menuntut agar Maroko diberi hak penuh untuk menentukan nasibnya sendiri disamping menuntut agar Sultan Yusuf dikembalikan (Kosoh, 1977: 75).

Setelah mendapat desakan kaum nasionalis, akhirnya Sultan Muhamamd bin Yusuf dikembalikan, dan protektorat diakhiri pada tahun 1957, Sultan Muhammad bin Yusuf menjadi Raja. Setelah wafat kedudukannya diganti oleh Sultan Hasan II (Kosoh, 1977: 77).

\section{Kebangkitan Aljazair}

Pergerakan nasional terjadi juga di Aljazair yang merupakan daerah jajahan Prancis.Bangsa Prancis banyak yang menetap di Aljazair sebagai kolonis, karena letaknya yang tidak jauh dari negara asal mereka. Disamping itu, suhu Aljazair sama dengan suhu udara Prancis (L. Stoddard, 1966: 101). Pergerakan nasional Aljazair dimulai ketika penduduk pribumi menuntut hak yang sama dengan para kolonis. Tuntutan penduduk pribumi itu terpaksa ditolak Perancis, karena apabila tuntutan itu dipenuhi maka kedudukan penduduk Perancis akan menjadi minoritas di Aljazair (L. Stoddard, 1966: 102).

Dalam usaha berjalan dan mencapai cita-cita rakyat Aljazair membentuk berbagai organisasi perjuangan, diantaranya yang terkenal adalah Front Pembebasan Nasional yang dibentuk pada tahun 1954. Diantara para Pejuang Aljazair terdapat seorang wanita yang dikenal dengan namaSrikandi Aljazair yaitu Jamilah (Kosoh, 1977: 82). Untuk menghadapi perjuangan penduduk pribumi kaum kolonis membentuk Organisasi Militer Rahasia yang mendapat dukungan militer Perancis dibawah pimpinan Jenderal Raoul Salan.

Para kolonis itu menentang usaha yang mau melepaskan diri dari kekuasaan Perancis di Aljazair. Setelah Prancis menganut politik dekolonisasi dibawah pimpinan Jenderal de Gaulle, di Aljazair segera diadakan penentuan pendapat rakyat (Pepera), yang menjadikan Aljazair sebagai negara republik pada tahun 1962. Ferhat Abbas diangkat menjadi Presiden Aljazair yang pertama, dan Ahmad Ben Bella menjadi Perdana Menterinya (Kosoh, 1977 : 90).

\section{Kebangkitan Kenya}

Pada akhir abad ke 19, Kenya merupakan daerah pengaruh kekuasaan 
Inggris dan Jerman. Tetapi setelah Perang Dunia I dan Jerman berada di pihak yang kalah perang, maka Inggris menjadi protector/pelindung Kenya. Pada tahun 1920 status protector Kenya diubah menjadi daerah jajahan (Kosoh, 1977: 91).

Pergerakan nasional Kenya yang pertama lahir pada tahun 1944 dengan dibentuknya organisasi Kenya African Union.Salah seorang pimpinannya yang kemudian diangkat menjadi bapak kemerdekaan Kenya ialah Jomo Kenyata. Disamping itu terdapat pula organisasi suku Kikuyu yang mengadakan perlawanan gerilnya terhadap Inggris. Pada tahun 1952 Inggris menyatakan Kenya dalam keadaan darurat perang dan gerakan suku Kikuyu ditumpas.Para pemimpin pergerakan ditangkap termasuk Jomo Kenyata (Kosoh, 1977: 95).

Pergerakan nasional Kenya yang membawakan cita-cita dan aspirasi rakyat Kenya mulai terwujud pada tahun 1964 ketika pemerintah Inggris mengadakan referendum. Jomo Kenyata menjadi Perdana Menteri dan setahun kemudian Kenya menjadi negara Republik dengan Jomo Kenyata sebagai Presiden pertama.

Berdasarkan beberapa paparan tentang kebangkitan negara-negara di Afrika, maka terjadi juga kebangkitan nasional di daerah-daerah lain Afrika. Sejak Perang Dunia II selesai, beberapa negara Afrika berusaha untuk melepaskan diri dari ikatan kaum penjajah. Beberapa negara baru di Afrika muncul setelah diadakan Konferensi Asia Afrika tahun 1955 di Bandung, seperti Gabon, Kamerun, Kongo, Nigeria, Malawi, Togo, Malagasi, dan Anggola.

Beberapa negara baru dari negaranegara yang sudah adapun bermunculan seperti Zambia (Rhodesia Utara), Zimbawe Rhodesia dan lain-lainnya, baik karena daerah itu memang sudah berlainan sejak mereka memulai pergerakan maupun karena daerah tersebut melepaskan diri kemudian dari Pemerintah Pusat (Kosoh, 1977: 96).

Kemerdekaan adalah hak segala bangsa, dan oleh sebab itu penjajahan diatas dunia harus dihapuskan karena tidak sesuai dengan peri kemanusiaan dan peri keadilan. Hal ini tidak saja menjadi faham bangsa Indonesia, tetapi merupakan isi jiwa bangsa-bangsa lain khususnya bangsa Afrika dan umumnya negara di belahan dunia.

\section{Pengaruh Konferensi Asia Afrika Terhadap Negara-negara di Benua Afrika}

Munculnya Konferensi Asia Afrika di Bandung yang melahirkan "Dasasila Bandung" merupakan jawaban positif terhadap tantangan zaman pada waktu itu yang mengkaitkan perjuangan bangsabangsa terjajah terhadap kaum kolonialisme dan imperialisme yang masih bercokol di bumi Afrika.Khususnya di belahan bumi Afrika rakyat bangkit mengadakan 
perlawanan terhadap bangsa-bangsa penjajah dari kaum kolonialis-kolonialis itu (Roeslan Abdulgani, 1980: 149).

Sejak Perang Dunia II berakhir, kemudian menyusul diselenggarakan-nya Konferensi Asia Afrika di Bandung pada tahun 1955, dari 59 negara-negara Afrika hasil ciptaan kaum penjajah barat (kecuali tiga buah negara yang sudah merdeka sebelumnya), hampir semuanya kini sudah mencapai kemerdekaan penuh dibawah bangsa Afrika sendiri.

Sementara itu rakyat-rakyat dari negara-negara yang baru merdeka, kini masih berjuang dengan gigih dan maju dengan penuh keyakinan untuk memperkokoh kedaulatan negara, mengembangkan ekonomi nasional dan Melenyapkan sisa-sisa pengaruh kaum kolonialis sampai ke akar-akarnya. Satusatu negara yang belum merdeka yaitu Namibia (Widjaja, 1986: 69), pasukanpasukan front pembebas disana dengan dasyatnya mengadakan perlawanan yang tak mengenal lelah dan waktu.

Mereka bertempur melawan angkatan bersenjata kaum penjajah yang berkekuatan jauh lebih besar dan bersenjatakan serba modern. Demikian pula di Republik Afrika Selatan yang sampai sekarang masih dikuasai bangsa Inggris dan Belanda dengan gigih pula tetap mempertahankan politik ras diskriminasi, seperti apa yang dikenal dengan politik "apartheid", kaum Pejuang Negro Afrika berusaha dengan sekuat tenaga Melenyapkan politik Rasisme itu sesuai pula dengan tujuan dan azas Konferensi Bandung (Widjaja, 1986: 73).

Kaum gerilnya didaerah-daerah tersebut diatas seperti Namibia dan Afrika Selatan ditaksir mencapai jumlah ribuan orang. Pertempuran-pertempuran sengit harus berlangsung seperti halnya yang terjadi di negara-negara Timur Tengah atau di Vietnam-Kamboja (Widjaja, 1986:59). Dalam slogan itu rakyat dengan teguh menentang usaha-usaha kaum kolonialis yang hendak menunda-nunda pemberian kemerdekaan pada negeri-negeri Afrika. Peserta-peserta pada Konferensi Asia Afrika mengambil keputusan yang mendesak penghapusan sama sekali kekuasaan kolonial di Afrika pada tahun 1963.

Konferensi kedua dari negaranegara Afrika Merdeka dilangsungkan di Manrovia pada bulan April 1959. Dan bulan Januari 1960, 120 orang Delegasi dari 30 negeri Afrika bertemu dalam Konferensi Rakyat Afrika kedua di Tunisia. Dapat menyaksikan gerakan dari rakyat Afrika ini sebelumnya tidak pernah bersatu karena selalu dipecah-pecah atau dibagi-bagi dengan segala upaya untuk mencegah bangsa Afrika bersatu, untuk mengasingkan atau sepenuhnya mengisolasi rakyat Afrika satu dengan lainnya (Kosoh, 1977: 99).

Selain karena faktor alam seperti luasnya daerah Afrika, sulitnya Perhubungan, sistim kesukuan dan 
perbedaan bahasa, kaum kolonialis juga dengan sengaja memecah-mecah keutuhan negeri seperti Kongo dijadikan propinsipropinsi untuk menghindari ancaman dari suatu kekuatan Kongo. Dalam keadaan yang terpecah-pedah, tidaklah sulit untuk melihat betapa sukarnya bagi rakyat dari negeri Afrika yang satu untuk mengadakan hubungan sesama saudaranya didaerah Afrika lainnya.

Adapun pengaruh gerakan setia kawan yang merupakan inti Deklarasi Bandung terhadap Konferensi di Accra dan Tunisia yang secara gamblang dinyatakan bahwa semua bangsa di dunia dengan bebas dari perasaan curiga dan takut dengan saling mempercayai atau menunjukkan kemauan baik, serta dapat hidup bersama dalam perdamaian sebagai tenaga yang baik, adalah penekanan bahwa tujuan utama di kedua Konferensi itu pun yaitu untuk mencapai saling pengertian dan persatuan Afrika yang begitu pokok dari kemenangan perjuangan Pembebasan Afrika (Kosoh, 1977: 100).

Hal inilah yang merupakan pernyataan tegas yang disampaikan oleh Sekretaris Jenderal Diallo dalam Konferensi Rakyat Afrika itu (Kosoh, 1997: 103). Persatuan yang lebih kokoh serta saling mengerti dan setia kawan maupun aksi praktis dalam pelaksanaan tugas yang dihadapi oleh negeri-negeri Afrika selalu ditekankan oleh setiap pembicara baik dalam Konferensi Accra ataupun Konferensi
Tunisia. Konferensi ini akhirnya mendorong gerakan setiakawan Afrika yang mempunyai ciri dan tugas khusus, tetapi yang bersamaan dengan itu merupakan bagian dari gerakan setiakawan yang tersebar di semua negeri Afrika yang berjuang untuk penghapusan sepenuhnya dari sisa kolonial, untuk kemajuan dan masa depan yang gemilang (Kosoh, 1977: 103).

Jika Konferensi Bandung seperti halnya juga Konferensi Accra dan Tunisia lebih merupakan Konferensi politik dari pada Konferensi ekonomi, ini adalah memang suatu kenyataan. Oleh karena yang menjadi sasaran utama terlebih dahulu adalah kemerdekaan politik, sedangkan masalah-masalah ekonomi, kendati jelas tercakup dalam Dasasila Bandung tersebut, namun dalam kenyataan tidak mungkin dapat dilaksanakan sekaligus bersamaan.

Namun demikian sebagai salah satu langkah yang bertujuan melaksanakan bidang ekonomi adalah Konferensi Setia Kawan Asia Afrika yang dibuka di Kairo pada akhir tahun 1957. Dalam Konferensi itu diperbincangkan kemungkinan untuk meluaskan kerjasama dibidang ekonomi antar negeri-negeri Asia Afrika (Sartono Kartodirdjo, 1977: 374).

Konferensi tersebut mendesak penghapusan ketidakadilan yang terdapat dalam perdagangan antara negeri-negeri yang belum maju dan yang telah maju, mendesak pembentukan harga-harga bahan mentah yang layak dalam pasaran dunia, 
perdagangan yang lebih luas antara bangsa Asia Afrika dan lain-lain. Ini berarti perlu adanya suatu koordinasi mengenai rencana pembangunan ekonomi tersebut dapat direalisasikan, jelas bahwa rakyat dari negara-negara Afrika Merdeka benar-benar akan memegang peranan nama penting dalam perekonomian dunia, mengingat bahwa bumi Afrika ini seperti telah tersinggung mengandung sumber kekayaan yang tak ternilai (Kosoh, 1977 : 2).

Harapan rakyat Afrikan ataupun seluruh bangsa Asia segera dapat terwujud sesuai dengan cita-cita dan semangat yang terkandung dalam Konferensi Asia Afrika di Bandung tahun 1955. Betapa pun kuatnya pengaruh jiwa dan semangat Bandung terhadap sikap bangsa Afrika, dapat disaksikan ketika wakil Indonesia membicarakan masalah Irian Barat di Majelis Umum PBB pada tahun 1969.

Pada mulanya mendapat kesulitan karena mendapat tantangan dari wakil Ghana yang kemudian disokong oleh sejumlah 30 negara lainnya dengan alasan timbulnya kekhawatiran bahwa prinsip musyawarah dan mufakat yang dipakai terhadap Irian Barat akan ditiru oleh pemerintah rasialis yang pada waktu itu masih bercokol dibenua Afrika seperti Afrika Selatan dan Rhodesia dalam menghadapi gerakan kemerdekaan di Namibia atau Angola dan sebagainya. Menanggapi sikap Ghana dan pendukungpendukungnya, wakil Aljazair menjelaskan proses perjalanan sejarah perjuangan bangsa Indonesia dalam membebaskan tanah airnya termasuk Irian Barat. Mengingatkan bahwa di Bandung pada tahun 1955, Pejuang-pejuang kemerdekaan seluruh Asia Afrika di bela oleh Indonesia (Roeslan Abdulgani, 1980:6).

Pembicaraan Aljazair itu mengakibatkan jumlah suara 84 orang yang pro, yang kontra nihil dan 30 suara abstan. Sehingga jelaslah bahwa jiwa dan semangat Bandung tetap menyala dikalangan negaranegara Asia Afrika, khususnya sejumlah negara Afrika yang dipelopori Aljazair (Roeslan Abdulgani, 1980: 7). Contoh lain, mengenai pengaruh semangat Bandung ialah dalam menghadapi kemelut yang dialami rakyat Afrika khususnya yang melanda rakyat Mesir ketika timbulnya krisis Terusan Suez dimana negara-negara barat, terutama Inggris dan Perancis telah memilih cara kekerasan senjata untuk mencoba memulihkan kekuasaan mereka disana (Soebantardjo, 1956: 195).

Dalam hubungan dengan kegawatan internasional yang melibatkan Mesir, Pemerintah Indonesia segera menentukan politiknya sejalan dengan isi Dasasila yang merupakan keputusan bersama dalam Konferensi Asia Afrika di Bandung tahun 1955 (Roeslan Abdulgani, 1987: 400). Sumbangan kemiliteran Indonesia itu didasarkan atas pengertian bahwa pasukanpasukan polisi PBB memang bertugas semata-mata untuk memelihara perdamaian 
dan tidak akan bersifat suatu percampuran tangan didalam urusan-urusan dalam negeri dari negara-negara dimana pasukanpasukan tersebut ditempatkan. Di samping itu secara geografis kedua negara itu ada persamaan, hal ini sesuai dengan pendapat Bung Karno "Indonesia penjaga ujung Asia Tenggara, sementara Mesir penjaga ujung Asia Barat" (Roeslan Abdulgani, 1987: 400).

Dari pernyataan diatas, baik yang berkaitan masalah sikap Ghana dan pendukungnya semula yang menunjukkan kekhawatiran dan mengenai Krisis Terusan Suez yang dihadapi rakyat Mesir, semangat dan jiwa Bandung itu jelas dan tegas menunjukkan pengaruh positif terhadap perjuangan rakyat Afrika. Sekalipun antara harapan dan kenyataan masih belum menempatkan hasil yang menggembirakan. Namun peristiwa itu jelas tindak lanjut yang seirama dengan isi Dasasila Bandung dan bukan merupakan peristiwa yang hanya dikaitkan belaka. Sebab terjadinya Konferensi Apro/Asia 1955 di Bandung merupakan detik bersejarah bagi bangsa Asia Afrika khususnya dan dunia umumnya (Soebantardjo, 1956: 251).

\section{Penutup}

\section{A. Simpulan}

Konferensi Asia Afrika terjadi atas gagasan yang diajukan dalam Konferensi Kolombo, yang dihadiri oleh Indonesia, India, Birma, Pakistan dan Srilangka, pada bulan April tahun 1954. Usul Indonesia ini kemudian dimatangkan dalam Konferensi
Bogor yang diadakan pada akhir bulan Desember 1954. Konferensi Afrika berhasil diselenggarakan pada bulan April tahun 1955, dengan dihadiri oleh 29 negara.

Banyak tokoh dunia dari Asia Afrika yang menghadiri peristiwa bersejarah ini, seperti Pandit Jawaharlal Nehru dari India, Chou En Lai dari RRC, Gamal Abdul Nasser dari Mesir dan Norodom Sihanouk yang merupakan kepala pemerintahan yang termuda yang hadir dalam Konferensi. Konferensi Asia Afrika dibuka oleh Presiden Soekarno dan diketuai oleh Perdana Menteri Ali Sastroamidjojo dari Indonesia.

Pengaruh Konferensi Asia Afrika terhadap negara-negara di Benua Afrika merupakan jawaban positif terhadap tantangan jaman pada waktu itu yang mengkaitkan perjuangan bangsa-bangsa terjajah terhadap kaum kolonialis imperalis yang masih bercokol di bumi Afrika. Di belahan bumi Afrika rakyat sedang bangkit mengadakan perlawanan terhadap bangsabangsa penjajah dari Eropa Barat, menyadari pentingnya jiwa dan semangat Bandung.

Oleh karena mempunyai dampak yang tak ternilai terhadap gerak perjuangan dalam usaha membebaskan diri dari kaum kolonialis imperialis. Konferensi Asia Afrika Bandung tahun 1955, dapat dianggap sebagai momentum historis yang sangat penting dalam sejarah dunia. Konferensi Asia Afrika menaikkan citra Indonesia di dunia internasional dan khususnya bangsa 
Afrika. Selama Indonesia memegang Pancasila dan berdasarkan NKRI yang diproklamasikan tanggal 17 Agustus 1945 sebagai landasan berbangsa dan bernegara, maka semangat Bandung tetap menjadi suatu prinsip politik luar negeri bangsa Indonesia bebas aktif dalam upaya memberikan inspirasi terhadap negaranegara di Afrika.

\section{B. Saran}

1. Diharapkan pada generasi bangsa yang berada dikawasan Asia Afrika, segi moral harus menjadi kekuatan yang pertama. Sehingga sisa kolonialisme dan politik power negara besar dapat diantisipasi.

2. Kekuatan moral generasi bangsa yang berada di kawasan Asia Afrika, perlu ditransformasikan ke dalam bentuk "Kekuatan Moral" demi terwujudnya diseluruh dunia. Konferensi Asia Afrika tahun 1955 di Bandung dapat memberikan pupuk agar tumbuhnya benih nasionalis dan internasionalis dikawasan Asia Afrika. Kepada bangsa Afrika untuk mengatasi sekarang, begitu pun bangsa Asia, tidak ada jalan lain terkecuali harus memperkuat ketahanan nasionalnya di segala bidang, sambil menginjeksikan suara akal sehat Dasasila Bandung ke dalam kehidupan politik regional dan internasional.

\section{Daftar Pustaka}

Ali Sastroamidjojo. 1974. Tonggak-tonggak di perjalananku Kinta. Jakarta.
Ari J. Adipurwawidjaja, KAA dan Berdirinya Dunia Ketiga (I), Pikiran Rakyat, 24 April 2003.

A.H Nasution.Sekitar Perang Kemerdekaan Indonesia, Jilid I, Proklamasi, Disejarah AD. Angkasa. Bandung.

A.W. Widjaja. 1986. Indonesia Asia Afrika Non Blok Politik Bebas Aktif. Jakarta: Bina Aksara.

B.M. Diah. 1980. Arti Konferensi Bandung. Jakarta: Yayasan 17-08-1945.

Badan Penelitian dan Pengembangan Departemen Penerangan RI.1980. Sekitar Konferensi Asia Afrika. Jakarta.

Depdikbud. 1996. Sejarah Perjuangan Bangsa 50 Tahun Indonesia Merdeka. Jakarta.

Edi S. Ekadjati. 1980. Sejarah Singkat Konferensi Asia Afrika.Bandung: Museum KAA Bandung.

George Me. 1956. Tuman Kahin: Asian African Conference. Bandung: Cornell Univercity Press.

Kosoh Sastradinata dan Rusyai Padmawijaya. 1977. Sejarah Pergerakan Nasional Bangsa-Bangsa Afrika. Bandung: FKIP.

1985. Beberapa Catatan Sekitar I AA di Bandung dan Dampaknya Terhadap Gerakan Kemerdekaan Rakyat Afrika.Makalah IKIP Bandung.

Kirdi Dipoyudo. 1977. Afrika Dalam Pergolakan. Jakarta: Yayasan Proklamasi CSIS.

Kementerian Penerangan Indonesia.1955. Bangsa Indonesia Berjuang Menurut Garis Sejarah, Jakarta.

Mohamad Tito. 1980. Document of Asian African Conference. Bandung.

Marwati Djoened Poeponegoro. 1990. Sejarah Nasional Indonesia VI. Jakarta: Depdikbud. 